\title{
Determination of the Risk Factors in Patients Admitted with Bleeding Due to Warfarin use and Evaluation of the Current Bleeding Risk Scores
}

Varfarin Kullanımına Bağ̆ı Kanama ile Başvuran Hastalarda Risk Faktörlerinin Belirlenmesi ve Mevcut Kanama Risk Skorlarının Değerlendirilmesi

${ }^{1}$ Aykut Demirkiran, ${ }^{2}$ Abdulkadir Basturk, ${ }^{3}$ Samil Ecirli

${ }^{1}$ Department of Medical Oncology, Necmettin Erbakan University, Konya, Turkey

${ }^{2}$ Department of Hematology, Konya Training and Research Hospital, Konya, Turkey

${ }^{3}$ Department of Internal Medicine, Konya Training and Research Hospital, Konya, Turkey

\section{Correspondence:}

Aykut DEMIRKIRAN Department of Medical Oncology, Necmettin Erbakan University, Konya, Turkey e-mail: aykut_dmrkrn@hotmail.com

\section{Abstract}

Warfarin is the most common drug used in oral anticoagulation. The most serious side effect is bleeding. The aim of this study is to determine the risk factors that increase bleeding. In this retrospective study, we evaluated 283 patients with the diagnosis of bleeding due to warfarin use. The patients were divided into two groups as major and minor bleeding according to the need for blood transfusion. Age, gender, international normalized ratio (INR) level, drug use history, presence of additional disease, duration of treatment, warfarin dosage and laboratory data were obtained from patient files. Bleeding risk scores of 197 patients for whom laboratory data could be obtained before the bleeding event were calculated. The mean age of the patients was 69.16 \pm 12.90 years. $51.9 \%$ were female and $48.1 \%$ were male. The major bleeding group was older $(\mathrm{p}=0,007)$. The rate of drug use that interacts with warfarin was $53.3 \%$. Acetylsalicylic acid (ASA) usage rate was $31.4 \%$. ASA use was more common in the major bleeding group ( $\mathrm{p}=0,000$ ). Concomitant disease was detected in $86.9 \%$ of the patients. The most common concomitant diseases were heart disease $59 \%$, hypertension $56.5 \%$ and diabetes $21.2 \%$, respectively. Heart disease was more common in the major bleeding group ( $\mathrm{p}=0,001$ ). The hemoglobin value measured at least one month before the bleeding was found to be significantly lower in the major bleeding group ( $\mathrm{p}=0,001$ ). Only the ATRIA (Anticoagulation and Risk Factors in Atrial Fibrillation) median score was significantly higher in patients experiencing major bleeding than minor bleeding $(p=0.002)$. In our study, it was found that major bleeding due to warfarin was associated with advanced age, ASA use, concomitant heart disease and anemia development before bleeding. Therefore, close monitoring of the bleeding profile is very important. Patients and their care providers should be well informed about the side effects of the drug.

Keywords: Warfarin; oral anticoagulation; risk of bleeding; bleeding risk scores

\section{Özet}

Varfarin oral antikoagülasyonda kullanılan en yaygın ilaçtır. En ciddi yan etkisi kanamadır. Bu çalıșmanın amacı kanamayı artıran risk faktörlerini belirlemektir. Bu retrospektif çalı̧̧mada varfarin kullanımına bağlı kanama tanısı alan 283 hastayı değerlendirdik. Hastalar kan transfüzyonu ihtiyacına göre majör ve minör kanama olarak iki gruba ayrıldı. Hasta dosyalarından yaş, cinsiyet, uluslararası normalleştirilmiş oran (INR) düzeyi, ilaç kullanım öyküsü, ek hastalık varlığı, tedavi süresi, varfarin dozu ve laboratuvar verileri elde edildi. Kanama olayı öncesi laboratuvar verilerine ulaşılabilen 197 hastanın kanama risk skorları hesaplandı.

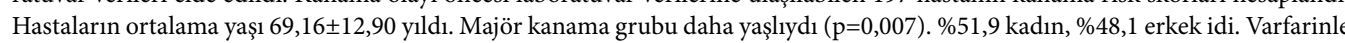
etkilesen ilâç kullanım oranı \%53,3 idi. Asetilsalisilik asit (ASA) kullanım oranı \%31,4’tü. ASA kullanımı majör kanama grubunda daha yaygındı $(\mathrm{p}=0,000)$. Hastaların \%86,9’unda eşlik eden hastalık varlığı tespit edildi. En sık eşlik eden hastalıklar sırasılyla kalp hastalığı $\% 59$, hipertansiyon $\% 56,5$ ve diyabet $\% 21,2$ olarak görüldü. Kalp hastalı̆ı̆ major kanama grubunda daha sıktı $(\mathrm{p}=0,001)$. Kanamadan en az bir ay önce bakılan hemoglobin değeri majör kanama grubunda anlamlı olarak daha düşük bulundu ( $\mathrm{p}=0,001)$. Majör kanaması olan hastalarda minör kanamaya göre sadece ATRIA (Anticoagulation and Risk Factors in Atrial Fibrillation) medyan skoru anlamlı olarak daha yüksekti $(p=0.002)$. Calışmamızda varfarine bağlı majör kanamanın ileri yaş, aspirin kullanımı, eșlik eden kalp hastalığı ve kanama öncesi anemi gelişimi ile ilişkili olduğu bulundu. Bu nedenle kanama profilinin yakın takibi çok önemlidir. Hastalar ve bakım sağlayıcıları ilacın yan etkileri hakkında iyi bilgilendirilmelidir.

Anahtar Kelimeler: Varfarin; oral antikoagulasyon; kanama riski, kanama risk skorları 


\section{Introduction}

Arterial and venous thrombosis is major causes of morbidity and mortality rates. Arterial thrombosis is the most common cause of acute myocardial infarction, ischemic stroke and leg gangrene, while deep vein thrombosis can lead to fatal pulmonary embolism (PE) and postphlebitic syndrome (1). Currently, there are oral (warfarin and other vitamin $\mathrm{K}$ antagonists) and parenteral (heparin, low molecular weight heparins, fondaparinux, hirudin, bivalirudin, lepirudin and argatroban) anticoagulant drugs that are licensed for use in the prophylaxis or treatment of these diseases. New agents have also been added to these agents in recent years. Warfarin is the most widely used oral anticoagulant in the world and blocks vitamin $\mathrm{K}$ dependent coagulation factors (II, VII, IX, $\mathrm{X})$ and vitamin $\mathrm{K}$ dependent coagulation inhibitors.

Since it has a very narrow therapeutic window, it is not possible to adjust the sufficient therapeutic dose in every patient (2). The effectiveness of warfarin is demonstrated by the international normalized ratio (INR) value, rather than measuring the drug level. For most indications, an INR of $2.5(2.0-3.0)$ is targeted, but $3.0(2.5-3.5)$ is predicted for patients with mechanical prosthetic heart valves (3). The most important complication of warfarin is bleeding. At values above INR 5.0, the risk of bleeding increases exponentially, but it is difficult to determine the exact risk in patients $(4,5)$. There are many factors that affect the occurrence of bleeding. In our study, we wanted to investigate the risk factors in cases with bleeding due to warfarin seen in our region by retrospectively examining the patients' files.

\section{Material and Methods}

In this study, a total of 283 patients diagnosed with bleeding due to warfarin use in the Internal Medicine Clinic of the Ministry of Health Konya Training and Research Hospital between September 1, 2010 and August 31, 2014 were retrospectively evaluated. By examining the patient files, the patient's age, gender, INR value, treatment duration, warfarin dosage, medication history, presence of additional disease, mortality rate and laboratory data were obtained. The patients were divided into two groups as major and minor bleeding according to the need for blood transfusion. The patient's need for 2 or more units of erythrocyte suspension for therapeutic purposes was defined as major bleeding, and the need for 1 unit of erythrocyte suspension or no need at all was defined as minor bleeding. The effects of the obtained data on major and minor bleeding were investigated. Bleeding risk scores of 197 patients, whose laboratory data could be obtained at least one month before the bleeding event, were calculated. The OBRI (Outpatient Bleeding Risk Index), HEMORR2HAGES (Hepatic or Renal Disease, Ethanol Abuse, Malignancy, Older Age, Reduced Platelet Count or Function, ReBleeding, Hypertension, Anemia, Genetic Factors, Excessive Fall Risk and Stroke), HAS-BLED (Hypertension, Abnormal Renal/Liver Function, Stroke, Bleeding History or Predisposition, Labile INR, Elderly, Drugs/Alcohol) and ATRIA (Anticoagulation and Risk Factors in Atrial Fibrillation) bleeding risk scores were computed according to original definitions (610).

OBRI includes four risk factors (age $\geq 65$ years, history of stroke, history of gastrointestinal bleeding, and comorbid disease). Patients were defined as "low risk" for 0 points, "intermediate risk" for 1-2 points, and "high risk" for 3-4 points (6).

The HEMORR2HAGES score assigned a score for: liver or kidney disease, ethanol abuse, malignancy, advanced age ( $\geq 75$ years), decreased platelet count or function, uncontrolled hypertension, anemia, genetic factors, risk of extreme falls, history of stroke. Patients were defined as "low risk" for 0-1 points, "moderate risk" for 2-3 points, and "high risk" for $\geq 4$ points. $(7,10)$.

In the HAS-BLED risk score, one point was assigned for the presence of uncontrolled hypertension (systolic blood pressure [BP] $>160 \mathrm{mmHg}$ ), impaired kidney or liver function, history of stroke, history of bleeding (or bleeding predisposition)., unstable INR, 
elderly (age $>65$ years), concomitant use of acetylsalicylic acid (ASA) or non-steroidal anti-inflammatory drugs (NSAIDs), and alcohol consumption (more than 20 units per week). A HAS-BLED score of $\leq 2$ was classified as "low risk", and a HAS-BLED score of $\geq 3$ was classified as "high risk" $(8,10)$.

The ATRIA score was assigned three points for the presence of anemia or a concomitant diagnosis of severe kidney disease (creatinine clearance $<30 \mathrm{ml} / \mathrm{min}$ ), 2 points for age $\geq 75$ years, and one point for a positive history of clinical bleeding or hypertension $(9,10)$.

\section{Statistical analyses}

While evaluating the findings obtained in the study, SPSS (Statistical Package for Social Sciences) for Windows 15.0 program was used for statistical analysis. Descriptive statistical methods (mean, standard deviation, frequency) were used while evaluating the study data. For the comparison of parameters not showing normal distribution between more than two groups, the Kruskal Wallis test was used and the Mann Whitney U test was used to identify the group that caused the difference. Two-group Student's t-test was used for parameters showing normal distribution, and Mann Whitney U test was used for two-group comparisons of parameters not showing normal distribution. Chi-square test was used to compare qualitative data. The results were evaluated at a $95 \%$ confidence interval, and the significance level was $\mathrm{p}<0.05$.

\section{Ethical approval}

Local Ethical Committee of Necmettin Erbakan University (Ethical approval license: Reference Number: 2014/45 Date: $05 / 12 / 2014$ ) approved the study protocol. We conducted the study according to the principles of the Declaration of Helsinki.

\section{Results}

A total of 283 patients retrospectively evaluated. Major bleeding was observed in $148(52.2 \%)$ patients. Clinical characteristics of patients according to major bleeding occurrence are summarized in in a table (Table 1).

Table 1. Descriptive and clinical characteristics of groups

\begin{tabular}{|c|c|c|c|}
\hline & Major bleeding $(n=148)$ & Minor bleeding $(n=135)$ & p value \\
\hline Age, (years) & $71,05 \pm 12,16$ & $67,10 \pm 13,41$ & $\mathrm{p}=0,007$ \\
\hline Age $\geq 65$ years $(n), \%$ & $107(72,3 \%)$ & $83(61,4 \%)$ & $\mathrm{p}=0,053$ \\
\hline Age $\geq 70$ years $(n), \%$ & $97(65,5 \%)$ & $67(49,6 \%)$ & $\mathrm{P}=0,007$ \\
\hline Sex (male), \% & $81(54,7 \%)$ & $55(45,3 \%)$ & $\mathrm{p}=0,513$ \\
\hline INR $>5$ & $90(60.8 \%)$ & $98(72.6 \%)$ & $\mathrm{p}<0,001$ \\
\hline Treatment duration $>1$ year & $83(62,4 \%)$ & $74(59,2 \%)$ & $\mathrm{p}=0,684$ \\
\hline Dosage $\geq 35 \mathrm{mg} /$ week & $91(61,5 \%)$ & $95(70,3 \%)$ & $\mathrm{p}=0,062$ \\
\hline ASA & $61(\% 41,2)$ & $28(\% 20,7)$ & $\mathrm{p}=0,000$ \\
\hline NSAIDs & $15(\% 10,1)$ & $22(\% 16,2)$ & $\mathrm{p}=0,125$ \\
\hline Clopidogrel & $5(\% 3,3)$ & $6(\% 4,4)$ & $\mathrm{P}=0,644$ \\
\hline Heart disease & $97(\% 65,5)$ & $70(\% 51,8)$ & $\mathrm{p}=0,001$ \\
\hline Hypertension & $80(\% 54,0)$ & $80(\% 59,2)$ & $\mathrm{p}=0,378$ \\
\hline DM & $30(\% 20,2)$ & $30(\% 22,2)$ & $\mathrm{p}=0,794$ \\
\hline History of Stroke & $33(\% 22,2)$ & $22(\% 16,2)$ & $\mathrm{p}=0,193$ \\
\hline History of MI & $28(\% 18,9)$ & $17(\% 12,5)$ & $\mathrm{p}=0,139$ \\
\hline History of GI bleeding & $13(\% 8,7)$ & $5(\% 3,7)$ & $\mathrm{p}=0,078$ \\
\hline Anemia & $50(53,2 \%)$ & $26(25,2 \%)$ & $\mathrm{p}=0,000$ \\
\hline Labil INR & $20(\% 21,3)$ & $28(\% 27,2)$ & $\mathrm{p}=0,337$ \\
\hline
\end{tabular}


Table 2. Bleeding risk score categories

\begin{tabular}{|c|c|c|c|c|}
\hline & Major bleeding & $\begin{array}{l}\text { Minor } \\
\text { bleeding }\end{array}$ & Overall & p value \\
\hline OBRI, median (IQR) & $1(0-4)$ & $1(0-3)$ & $1(0-4)$ & $\mathrm{p}=0,063$ \\
\hline \multicolumn{5}{|l|}{ OBRI } \\
\hline Low $(0)$ & $15(16 \%)$ & $24(23,3 \%)$ & $39(19,8 \%)$ & \\
\hline Intermediate (1-2) & $67(71,3 \%)$ & $75(72,8 \%)$ & $142(72,1 \%)$ & \\
\hline High $(3-4)$ & $12(12,8 \%)$ & $4(3,9 \%)$ & $16(8,1 \%)$ & \\
\hline HEMORR $_{2}$ HAGES, median(IQR) & $2(0-5)$ & $1(0-5)$ & $2(0-5)$ & $\mathrm{p}=0,094$ \\
\hline \multicolumn{5}{|l|}{ HEMORR ${ }_{2} \mathrm{HAGES}$} \\
\hline Low $(0-1)$ & $40(42,5 \%)$ & $53(51,4 \%)$ & $73(47,2 \%)$ & \\
\hline Intermediate $(2-3)$ & $40(42,5 \%)$ & $45(43,7 \%)$ & $85(43,1 \%)$ & \\
\hline High $(>3)$ & $14(14,9 \%)$ & $5(4,9 \%)$ & $19(9,6 \%)$ & \\
\hline HAS-BLED, median (IQR) & $2(0-5)$ & $2(0-5)$ & $2(0-5)$ & $\mathrm{p}=0,349$ \\
\hline \multicolumn{5}{|l|}{ HAS-BLED } \\
\hline Low $(0-2)$ & $61(64,9 \%)$ & $76(73.8 \%)$ & $137(69,5 \%)$ & \\
\hline $\operatorname{High}(>2)$ & $33(35,2 \%)$ & $27(26,2 \%)$ & $60(30,4 \%)$ & \\
\hline ATRIA, median (IQR) & $3(0-8)$ & $1(0-5)$ & $2(0-8)$ & $\mathrm{p}=0,002$ \\
\hline \multicolumn{5}{|l|}{ ATRIA } \\
\hline Low $(0-3)$ & $54(57,5 \%)$ & $82(\% 79,6)$ & $136(69,1 \%)$ & \\
\hline İntermediate/high $(\geq 4)$ & $40(42,5 \%)$ & $21(\% 20,4)$ & $61(30,9 \%)$ & \\
\hline
\end{tabular}

$136(51.9 \%)$ of the patients were men and 147 $(48.1 \%)$ were women, and the mean age of the patients was $69,16 \pm 12,90$ years. There was no significant difference in terms of gender between the groups $(p=0,513)$. Patients in the major bleeding group were older, and the mean age 71,05 vs 67,10 years $(p=0,007)$.

$60.8 \%$ of the patients in the major bleeding group and $72.6 \%$ of the patients in the minor bleeding group had an INR level of 5 and above $(p<0.001)$.. When the patient groups were compared in terms of warfarin dose, the difference was not statistically significant $(\mathrm{p}=0.062)$. Warfarin was mostly used at a dose of $35-50 \mathrm{mg} /$ week in both groups.

$49.8 \%(n=141)$ of patients had no history of drug use that interacted with warfarin. The rate of using drugs interacting with warfarin in the major bleeding group was $53.4 \%(\mathrm{n}=$ $79)$, and $46.7 \%(\mathrm{n}=72)$ in the minor bleeding group. ASA was the most commonly used drug in both groups. The use of ASA was statistically significantly higher in the major bleeding group $(\mathrm{p}=0.000)$.

Except for the warfarin indication, $86.9 \%$ ( $\mathrm{n}=$ 246) of the patients had at least one concomitant disease. The most common indications for warfarin use were atrial fibrillation $(32.9 \%)$ and heart valve disease $(36.7 \%)$. Concomitant disease was found in $87.8 \%(n=130)$ in the major bleeding group and $85.9 \%(n=116)$ in the minor bleeding group. Of all patients, 59\% $(\mathrm{n}=167) \quad$ heart disease, 56.5\% $\quad(\mathrm{n}=160)$ hypertension, 32.7\% $(n=60)$ diabetes, 19\% $(\mathrm{n}=54)$ chronic obstructive pulmonary disease, $6.3 \%(\mathrm{n}=18)$ chronic renal failure, $2.4 \%(\mathrm{n}=7)$ malignancy and $0.3 \% \quad(\mathrm{n}=1)$ chronic liver disease were seen. While no statistically significant difference was found in patients with hypertension $(\mathrm{p}=0.378)$ and diabetes $(\mathrm{p}$ $=0.794)$, a significant statistical difference was found in patients with heart disease $(\mathrm{p}=$ $0.001)$.

When the laboratory data of the patients at least one month before the bleeding event were examined, anemia was significantly more common in the major bleeding group $(54.3 \%$ vs $25.2 \%, \mathrm{p}=0,001)$. Labile INR was detected in $21.3 \%(\mathrm{n}=20)$ in the major bleeding group and $27.2 \%(\mathrm{n}=28)$ in the minor bleeding group (0.037).

Bleeding risk scores of 197 patients from 283 patients, whose laboratory data before bleeding were obtained from the hospital information system, were evaluated in terms of major and minor bleeding (Table 2). There was no statistically significant difference in 
median scores of HAS-BLED $(p=0.349)$, HEMORR2HAGES $(p=0.094)$ and OBRI $(p$ $=0.063$ ) between major and minor bleeding groups. Only the ATRIA median score was significantly higher in patients experiencing major bleeding than minor bleeding $(\mathrm{p}=$ 0.002 ).

Mortality was observed in only two (0.007\%) of our patients included in the study, and both were in the major bleeding group. One of the reasons for the low mortality was that patients presenting with intracranial bleeding complication were not included in the study.

\section{Discussion}

The most important complication that restricts the use of warfarin is bleeding. Bleeding due to warfarin use is more common in the elderly. In a study, it was found that patients with atrial fibrillation (AF) aged 70 years and older are at high risk. It was found that being 70 years or older carries a 1.63 times higher risk of bleeding (11). In the study conducted by Wallvik et al., an increased risk of bleeding was found 1.6 times less than 60 years old, 2.9 times in patients between 60 and 69 years old, 4.8 times in patients between 70 and 79 years old, and 6.6 times in patients aged 80 and over (12). In our study, the mean age of the patient group was found to be $69.16 \pm 12.90$ years. It was determined that the major bleeding group was older. The incidence of major bleeding was higher in patients aged 70 years and over $(p=0.007)$. When the data of the World Health Organization (WHO) is examined, it is seen that the elderly population is increasing in developed countries (13). Also, considering the prevalence of atherosclerotic diseases (such as strokes, ischemic heart diseases) in this age period, it is understood that age is an important parameter. Therefore, we think that before starting warfarin treatment, physicians should take this situation into consideration and provide better follow-up and information in the elderly group.

Gender is very important in the pharmacokinetic and pharmacodynamic effects of drugs. The place of gender is controversial regarding the bleeding complication of warfarin. Studies emphasizing that there is no male or female superiority or gender have been reported. In our study, we could not detect the effect of gender on major and minor bleeding. Male gender was observed more in the major bleeding group and females in the minor bleeding group.

Bleeding due to warfarin therapy correlates with the degree of anticoagulant therapy. But elderly patients are more sensitive to warfarin, a lower dose is sufficient to achieve therapeutic value and they are more prone to bleeding, including intracranial hemorrhage, even if their INR is in the therapeutic range. In addition, elderly patients are more likely to use one or more drugs that interact with warfarin (3). In the study, the rate of patients with INR $>5$ was found to be higher in the minor bleeding group and the weekly warfarin dose was also found to be higher. We think that this difference is due to the older age of the main bleeding group, the presence of more co-morbidities, and the higher use of drugs that interact with warfarin, such as ASA.

Drugs that affect warfarin metabolism produce different effects on INR levels depending on the inhibition or activation of the CYP2C9 enzyme (14). Therefore, we investigated the use of drugs (ASA, NSAIDs, heparin, clopidogrel, antiepileptics, antibiotics, antidepressants, antihyperlipidemics, thyroid drugs, amiodarone, allopurinol, and metformin) among patient groups. In our study, a significant difference was observed between the groups in terms of using only ASA. In a study by Kathleen M. Galatro et al. comparing patients who took warfarin alone with patients who received a combination of warfarin and low-dose ASA, they found that the frequency of both minor and major bleeding was higher in the group of patients receiving the combination treatment (15). Dentali $\mathrm{F}$ et al. and James D. Douketis reported that the risk of bleeding was 1.5-2 times higher in patients using ASA and warfarin combination, similarly $(5,16)$. Especially NSAIDs and randomly used ASA are drugs that are frequently prescribed and increase the risk of bleeding with warfarin. We recommend that these drugs should not be used together with warfarin as much as possible, if it is necessary to apply to the patient, the frequency of INR 
follow-up should be increased and the patient should be informed about this issue.

When the rates of comorbidities in both groups were compared, it was found that the rates of comorbidities were higher in the major bleeding group. Several studies emphasize that the presence of an accompanying disease is a risk factor for bleeding. The most common accompanying diseases in the study of Shireman et al. were hypertension and heart disease (11). In our study, the most common accompanying diseases were heart disease and hypertension, respectively. A significant statistical difference was found between groups in patients with heart disease $(p=0.001)$. One of the reasons why the patient group with concomitant diseases is more risky in terms of major bleeding is the use of multiple drugs in these patients.

Anemia before the bleeding event was more common in the major bleeding group. Although we have not been able to determine the mechanism of association, the anemia may reflect bleeding susceptibility or recent subclinical bleeding.

\section{REFERENCES}

1. Jameson J, Fauci AS, Kasper DL, Hauser SL, Longo DL, Loscalzo J. Harrison's Principles of Internal Medicine. 20th ed. McGraw Hill; 2018.

2. Moyer TP, O'Kane DJ, Baudhuin LM, Wiley CL, Fortini A, Fisher PK, et al. Warfarin sensitivity genotyping: a review of the literature and summary of patient experience. Mayo Clin Proc. 2009;84:1079-94.

3. Goldman L. (., Schafer, A. I., \& Cecil, R. L. 1. GoldmanCecil medicine (26th edition.). Philadelphia, PA: Elsevier. 2020

4. Keeling D, Baglin T, Tait C, Watson H, Perry D, Baglin C, Kitchen S, Makris M; British Committee for Standards in Haematology. Guidelines on oral anticoagulation with warfarin - fourth edition. Br J Haematol. 2011 ;154:31124.

5. Dentali F, Ageno W, Crowther M. Treatment of coumarinassociated coagulopathy: a systematic review and proposed treatment algorithms. J Thromb Haemost. 2006 ;4:1853-63

6. Beyth RJ, Quinn LM, Landefeld CS. Prospective evaluation of an index for predicting the risk of major bleeding in outpatients treated with warfarin. Am J Med. 1998;105:91-9.

7. Gage BF, Waterman AD, Shannon W, Boechler M, Rich MW, Radford MJ. Validation of clinical classification schemes for predicting stroke: results from the National Registry of Atrial Fibrillation. JAMA. $2001 ; 285: 2864-70$.

8. Lip GY, Frison L, Halperin JL, Lane DA. Comparative validation of a novel risk score for predicting bleeding risk in anticoagulated patients with atrial fibrillation: the HASBLED (Hypertension, Abnormal Renal/Liver Function, Stroke, Bleeding History or Predisposition, Labile INR, Elderly, Drugs/Alcohol Concomitantly) score. $\mathrm{J} \mathrm{Am} \mathrm{Coll}$ Cardiol. 2011;57:173-80.
Although it is not widely used today, scoring systems such as OBRI, HEMORR2HAGES, HAS-BLED and ATRIA are available for patients who will start warfarin (6-9). When the bleeding risk scores were examined in terms of major and minor bleeding in this study, ATRIA was found to be statistically significant. We think that giving more than 1 point to advanced age and anemia parameters in ATRIA risk scoring reveals this difference.

\section{Conclusion}

In patients using warfarin, the INR target value range should be determined according to the risk status of each patient, and close INR controls should be performed until the target INR value is reached. Major bleeding is the most important cause of morbidity and mortality in the event of a possible overdose. In our study, it was found that major bleeding due to warfarin was associated with advanced age, aspirin use, concomittant heart disease and anemia development before bleeding. Therefore, regular use of warfarin and close monitoring of the bleeding profile are very important. Patients and their care providers should be well informed about the side effects of the drug.

9. Fang MC, Go AS, Chang Y, Borowsky LH, Pomernack $\mathrm{NK}$, Udaltsova $\mathrm{N}$, et al. A new risk scheme to predict warfarin-associated hemorrhage: The ATRIA (Anticoagulation and Risk Factors in Atrial Fibrillation) Study. J Am Coll Cardiol. 2011;58:395-401.

10. Proietti M, Hijazi Z, Andersson U, Connolly SJ, Eikelboom JW, Ezekowitz MD, et al.; RE-LY Investigators. Comparison of bleeding risk scores in patients with atrial fibrillation: insights from the RE-LY trial. J Intern Med. 2018;283:282-92.

11. Shireman TI, Mahnken JD, Howard PA, Kresowik TF, Hou Q, Ellerbeck EF. Development of a contemporary bleeding risk model for elderly warfarin recipients. Chest. 2006;130:1390-6.

12. Wallvik J, Själander A, Johansson L, Bjuhr O, Jansson JH Bleeding complications during warfarin treatment in primary healthcare centres compared with anticoagulation clinics. Scand J Prim Health Care. 2007;25:123-8.

13. Organization WH; Health Statistics And Health İnormation Systems. WHO Mortality Database: Http://Www. Who. İnt/Whosis/Database/Mort/Table1. Cfm (Consulted 16 September 2010), 2010.

14. Özgenel DŞ. Varfarine Bağlı Kanamalarda Risk Faktörlerinin Karşılaştırılması. Uzmanlık Tezi; 2010.

15. Galatro KM, Adams PC, Cohen M, McBride R, Blanke H. Bleeding Complications and INR Control of Combined Warfarin and Low-Dose Aspirin Therapy in Patients with Unstable Angina and Non-Q-Wave Myocardial Infarction. J Thromb Thrombolysis. 1998;5:249-55.

16. Douketis J.D. Perioperative management of patients receiving anticoagulant or antiplatelet therapy: a clinicianoriented and practical approach. Hospital practice (1995), 2011;39:41-54. 